\title{
Ozone therapy for vial hepatitis. What can be expected? [abstract]
}

\author{
Heinz Konrad
}

Brazil

\section{ABSTRACT}

\section{OPEN ACCESS}

\section{Citation}

Konrad H. Ozone therapy for vial hepatitis. What can be expected? [abstract]. Proceedings of The World Conference on Ozone Therapy in Medicine, Dentistry and Veterinary. Ancona (Italy). September 22nd - 23rd - 24th , 2017. J Ozone Ther. 2019;3(4):31. doi: 10.7203/ jo3t.3.4.2019.15514

\section{Academic Editor} Jose Baeza-Noci, School of Medicine, Valencia University, SPAIN

\section{Editor}

World Federation of Ozone Therapy, Bolgna, ITALY

\section{Received}

June 17, 2019

\section{Accepted}

December 08, 2019

Published

December 30, 2019

\section{Intellectual Property}

Heinz Konrad.

This is an open access article distributed under the terms of the Creative Commons Attribution License (CC BY 4.0), which permits unrestricted use, distribution, and reproduction in any medium, provided the original author and source are credited.

\section{Author Information}

konrad@sti.com.br
Patients with acute viral hepatitis (type $A, B, C$ ) should receive high dosage OT at least twice weekly, expecting a fast decline of transaminases and bilirubins, as well as a fast clinical (subjective) recovery. On average, six sessions of OT will suffice. In the author's experience, this program will avoid the possible chronification of the disease.

Patients with chronic viral hepatitis (type $\mathrm{B}, \mathrm{C}$ ) normally require longer treatment, with two OT sessions weekly, for at least six weeks, after which the laboratory work should be remade. A reduction of transaminases is expected to occur, signifying a reduction in the intensity of the ongoing inflammatory process. An OT "maintenance" program is then recommended for at least six months, testing the transaminases regularly. Viral load negativization may or may not occur, but should not be THE goal of this treatment. During the OT, the viral load may vary immensely, and we have no sure explanation for this as yet. The author considers the viral load not to be a reliable criterion for the evaluation of the efficacy of ozone therapy for chronic viral hepatitis.

For legal as well as medical reasons, the author recommends NOT to apply ozone therapy and Interferon / Ribavirin treatments at the same time.

The real efficacy and long term safety of the newer medicines for acute and chronic viral hepatitis seem very positive, but may / should still be observed / cleared. 